\title{
Characteristics of Social Entrepreneur: An Explorative Analysis
}

\author{
Beatrice Orlando \\ Sapienza University of Rome, Rome, Italy \\ Maria Antonella Ferri \\ Universitas Mercatorum, Rome, Italy
}

\begin{abstract}
This study focuses on social ventures as for-profit organizations which base their survival on social legitimacy and generate a social value, by employing usually marginalized categories of individuals. Specifically, this paper studies main characteristics of starting a business in case entrepreneurs springs from a disadvantaged group of people. We use a an extremely large-scale sample, at worldwide level, including 1,563 observations. The time span covers the period 2004-2018. We investigate main characteristics of starting a business considering census (low and low-medium income) of the founder and gender. We perform one-way Anova and correlation statistics. Our results confirm that, despite policy makers' efforts, underdog individuals still have poor possibilities of starting a business because of capital required. Difficulties are greater for women than for men. The main limits of the analysis are the small number of variables used to investigate social ventures and the explorative method, which does not allow detecting causal relationships. At a macro-level, the paper shows that policies for incentivizing social entrepreneurship and social development are still scarcely effective. This contribution extends the knowledge in a field of research which is rather new. We originally contribute by digging to light that differences in gender are a poor explanation for social entrepreneurship. Findings are largely reliable because of the massive number and time-coverage of observations. Routinely collected observations are deemed to be less biased than cross-sectional analysis. Thus, the study detects a salient path in social entrepreneurship.
\end{abstract}

Keywords: for-benefit companies, social entrepreneurship, disadvantaged groups, social legitimacy

\section{Introduction}

For most of the twentieth century, for-profit corporations have been regarded as a type of legal, unchanging fabrications of the law, supported by a well-developed body of jurisprudence.

However, corporations have long been criticized as unmindful of their relationship with society (Hiller, 2013). For this reason, some entrepreneurs, managers, and governments have become more open to rethinking the traditional corporation. An impassioned social enterprise movement has sprung from this openness and within the social enterprise world.

Current study focuses on social ventures. This kind of firms operates along a continuum of behaviors in which they ignore, adopt, or embrace social welfare goals. They are "hybrid" forms of organizations, an

Beatrice Orlando, Ph.D., adjunct professor, Strategies for Business Growth, Department of Management, Sapienza University of Rome, Rome, Italy.

Maria Antonella Ferri, Ph.D., associate professor, Business Management, Universitas Mercatorum, Rome, Italy.

Correspondence concerning this article should be addressed to Beatrice Orlando, Department of Management, Sapienza University of Rome, Rome Castro Laurenziano 9, 00161, Italy. 
in-between category where private sake merges with social mission.

The existence of such organizational diversity suggests that forms of business organization should be viewed not as mere "receptacles" of assets, but as legally constructed "signals" that drive the strategic behavior of market participants and act as potential catalysts in the creation or destruction of operational norms. In other words, for a long time, the assumption for motivating the genesis of a business was the logic of shareholders value creation. But what does "maximizing shareholder value" mean? This question has been at the heart of academic debate for decades. Recently, terms such as "sustainable", "socially responsible", "public benefit", and "ethic" - that only decades ago would seem to have been the jargon of non-profits—have become a part of the lexicon of for-profit entities. This marks a shift from private to social sake when interpreting shareholders value creation. As the consequence, new forms of entrepreneurship aroused. Lately, legislation acknowledged their existence by an explicit recognition with ad-hoc legal provisions. In the midst of different labels, social entrepreneurship better portrays this twofold mission. Whilst some countries, as instance as US, have already long been adopting a specific legislation for social ventures, only recently Italy conformed to this provision.

At large, the peculiarity of social ventures is that they pursue a social benefit in addition to maximization of shareholders' value. Though, academia does not agree on the definition of social venture and on the nature of social benefit. As a consequence, this topic can be viewed by adopting multiple theoretical angles. One relevant research domain considers gender, census, and geography of initiator. The implicit assumption is that entrepreneurial initiative triggered by marginalized categories of individuals is a social benefit itself, since it produces a social development. Thus, we wonder how much the promotion of social development through supporting entrepreneurial initiatives in disadvantaged categories of individuals is effective. Precisely, we investigate social entrepreneurship by considering characteristics of founder. Our aim is to understand whether there are greater difficulties in disadvantaged groups of individuals to start up a business or not, in presence of ad-hoc public policies. To this end, we conduct a statistic analysis on a large-scale sample. Findings confirm that disadvantaged groups encounter extreme difficulties when starting a new business, although it seems that there are no particular gender differences.

\section{Theoretical Framework}

\section{Social Entrepreneurship and Social Context}

Most prior scholars investigate social entrepreneurship as a means to raise the social status of entrepreneur. In this stream, some studies focus on how it helps to escape from an unprivileged position (Korten, 1980; Alvord, Brown, \& Letts, 2004). Others consider entrepreneurship as a way to solve both the unemployment issue (Fairlie, 2005) and the problem of exclusion of minorities (Jack \& Anderson, 1999; Anderson, L. P. Dana, \& T. E. Dana, 2006; De Clercq \& Honig, 2011). Additionally, some scholars investigate whether minority groups can be differentially affected by public entrepreneurship programs or not (Lyons \& Zhang, 2017). Herring (2004) examines the relationship among entrepreneurship, poverty, and inner city communities by considering the ethnic enclave theory. Fairlie and Lofstrom (2015) study the relationship among immigration, entrepreneurship, and group differences in entrepreneurial success. Gender difference in entrepreneurial success and government policies is probably the most hot topic under the research radar (Marlow, Carter, \& Shaw, 2008). A one-of-a-kind study is the contribution on underdog entrepreneurs, which analyzes how negative circumstances one experiences in life could lead the individual to become a resilient and successful 
entrepreneur (Miller \& Le Breton-Miller, 2016). Another interesting stream of study is flourished on the concept of social innovation as a tool for the inclusion of marginalized people (Grimm, Fox, Baines, \& Albertson, 2013). We also observe that this entrepreneurship species often goes to alternative labels, such as ethnic entrepreneurship (Masurel Nijkamp, Tastan, \& Vindigni, 2002; Volery 2007), community entrepreneurship (Selsky \& Smith, 1994), and minority entrepreneurship (Bates, 2011).

\section{Meanings of Social Entrepreneurship and Prior Findings}

The main characteristic of social entrepreneurship is having achieved social goals. As Mair and Noboa (2006, p. 121) argue, social entrepreneurship "involves innovative approaches to address issues in the domains of education, environment, fair trade, health and human rights and is widely regarded as an important building block of the sustainable development of countries." However, social entrepreneurship arises as the contested concept (Choi \& Majumdar, 2014). This genus of firm is deemed to be compassion driven (Miller, Grimes, McMullen, \& Vogus, 2012) and is mostly described in a tautological manner. Mair and Marti (2006) observe that scholars offer different descriptions of what social entrepreneurship is, mostly anedoctical, which highlights individual attitude towards pursuign social benefit. This conception of social entrepreneurship has some major inherent issues. In fact, it appears extremely blurred for the implicit to undertake that social entrepreneurs are passionate individuals who wish to achieve collective benefit. Scholars wrongly assume that one's subjective vision of social good is aligned to social welfare optimum (Cho, 2006) and that social means ethic (Chell, Spence, Perrini, \& Harris, 2016). Not surprisingly, social entrepreneurship has been labeled caring capitalism (Hibbert, Hogg, \& Quinn, 2005). This heroic narrative, scarcely supported by empirical analyses, leads to a major misconception of what social entrepreneurship really is, how it processes up, how it springs, and for what reasons. As the consequence, most studies seep an extreme do-gooder envision of social entrepreneurship.

What emerges is a poor understanding of the intrinsic reasons why individual entrepreneur should pursue social benefits. Though, some scholars distance themselves from this scarcely objective, personality-centered vision of social entrepreneurship.

One important stream pays attention to objective determinants of social entrepreneurship. Anderson and Miller (2003) investigate the impact of high social class on entrepreneurial attitude. Both Kerlin (2006) and Defourny and Nyssens (2010) describe divergence and convergence in conception of social entrepreneurship between Europe and US. Hoogendoorn (2016) argues social entrepreneurship is favored by institutional circumstances. Giannetti and Simonov (2004) investigate to what extent differences in population, business environment, and cultural values contribute to explaining differences in entrepreneurial activity across population. Finally, one relevant antecedent to current study is the work of Datta and Gailey (2012). The two authors explain how social entrepreneurship in developing countries could serve as a means to empower women, at least in three ways: economic security, development of entrepreneurial behavior, and increased contributions to the family.

\section{Hypotheses of the Study}

Entrepreneurship studies have experienced an intense surge in recent years. Despite this, academia still lags far behind practice. Having witnessed proliferation of either hybrid or brand new forms of entrepreneurship, scholars have progressively shifted their attention from established and traditional topics to 
new entrepreneurial panorama. However, it seems that managerial studies cannot keep the pace of practice and, thus, they are in a relentless gasping. The disunity between academia and practice has, at least, two main consequences: (a) some relevant new forms of entrepreneurship are yet either under investigation or at a very embryonic phase; (b) there is poor understanding of phenomena, along with fuzzy descriptions, which both lead to confusion and overlapping. That is precisely the case of social entrepreneurship.

One peculiar trait of social entrepreneurship is that often entrepreneur is an unconventional individual, because of its social condition, context, age, or endowment of resources, not to mention other personal or exogenous traits. This kind of entrepreneurship implicitly entails an early disadvantaged status. At large, we assume opportunities recognition and prosecution occurs differently because of social class, gender, and context. All these factors affect the possibility to become a (social) entrepreneur and the envision of social mission. We further assume that creating a start up is far more challenging for social entrepreneurs than for traditional ones. We focus on how census conditions impact the starting of a social business. Consistently, we formulate the following research questions: (i) does the initial financial condition influence the possibility to become a social entrepreneur? (ii) how much is the gender worth? Consistently, we draw the following hypotheses:

$\mathrm{Hp}_{1}$ : there is a negative relationship between starting a business and time, cost, procedures, or paid-in minimum capital required to start up a business in disadvantaged groups.

$\mathrm{Hp}_{2}$ : there is a negative relationship between being a women and starting a business.

Prior studies in entrepreneurship usually consider being a female as an obstacle to entrepreneurship. Similarly, income of individuals could predict their attitude toward entrepreneurship. By searching in depth and breadth, we have found that scant researches focus on similar themes in social entrepreneurship.

\section{Empirical Investigation}

\section{Sample}

The study is conducted on an extreme large-scale sample. Observations have a worldwide coverage and are aggregated per country-level. In total, the sample includes 3,526.00 observations. We use archival data retrieved from the online repository of the World Bank, from a report labeled "doing business". We download data related to section named "starting a business". We distinguish two different sets based on individual income: low and low medium income; upper middle and high income. Observations are routinely collected for a period of 14 years, from 2004 to 2018. Size and temporal extension of the set allows performing a longitudinal analysis, thus having excluded most of the common biases in statistical researches. In detail, the large size of the set increases reliability, whereas routinely collected data allow detecting over-time patterns.

\section{Method and Variables}

As for the analysis, we measure one-way analysis of variance and correlation statistics. The analysis was repeated for each of the two different sets. Grouping was employed to make comparisons based on census information. Anova test serves as a means to exclude that the null hypothesis is true. Correlations are useful to explain linear relationships between couple of variables. Our dependent variable is starting a business. Independent variables are: procedures, time, cost, minimum capital. We use gender and income as control variables.

\section{Findings}


Results of Anova tests allow rejecting the null hypothesis (first type error) and accepting the alternative hypothesis (second type error) in both groups. The means appears significantly heterogeneous in each case:

Group one: one-way Anova, $\mathrm{F}_{7}, 10816=75.52651244, \mathrm{P}=2.5202 \mathrm{E}-107 ; \mathrm{F}_{7}, 10816=75.52651244>\mathrm{F}$ sig. $=$ 2.010433975, with a probability of being obtained, starting from homogeneous groups, $p=2.5202 \mathrm{E}-107$ (with $\mathrm{a}=0.05)$. Results are showed in Table 1 .

Table 1

One-Way Analysis of Variance (Anova) Low and Low Medium Income

\begin{tabular}{lllllll}
\hline $\begin{array}{l}\text { Origin of the } \\
\text { variation }\end{array}$ & Sum of squares & $\begin{array}{l}\text { Degrees of } \\
\text { freedom }\end{array}$ & Mean square & F & $p$ & F sig \\
\hline Between groups & 19.678 .409 & 7 & $2,811.201$ & 75.52651244 & $2.5202 \mathrm{E}-107$ & 2.010433975 \\
Within groups & $4.03 \mathrm{E}+08$ & 10,816 & $37,221.38$ & & & \\
& & & & & & \\
Total & $4.22 \mathrm{E}+08$ & 10,823 & & & & \\
\hline
\end{tabular}

Source: our elaboration.

Group two: one-way Anova, $\mathrm{F}_{6}, 11123=72.61401, \mathrm{P}=3.50251 \mathrm{E}-89 ; \mathrm{F}_{6}, 11123=72.61401>\mathrm{F}$ sig. $=$ 2.099408517, with a probability of being obtained, starting from homogeneous groups, $p=3.50251 \mathrm{E}-89$ (with $\mathrm{a}=0.05)$. Results are showed in Table 2.

Table 2

One-Way Analysis of Variance (Anova) Upper Middle and High Income

\begin{tabular}{lllllll}
\hline $\begin{array}{l}\text { Origin of the } \\
\text { variation }\end{array}$ & Sum of squares & $\begin{array}{l}\text { Degrees of } \\
\text { freedom }\end{array}$ & Mean square & F & $p$ & F sig. \\
\hline Between groups & $1,052,302.409$ & 6 & $175,383.7$ & 72.61401 & $3.50251 \mathrm{E}-89$ & 2.099408517 \\
Within groups & $26,865,247.41$ & 11,123 & $2,415.288$ & & & \\
& & & & & & \\
Total & $27,917,549.82$ & 11,129 & & & & \\
\hline
\end{tabular}

Source: our elaboration.

Also, the size of the sample is large enough, so that observations within each group are approximately normally-distributed. As for this reason, we can conclude the possibility the null hypothesis $\left(\mathrm{H}_{0}\right)$ is true and can be rejected.

Tables 3 and 4 show correlation statistics for each group. Main correlations are opportunely underscored. Results in Table 3 suggest that starting a business is negatively related with number of procedures, time, costs per capita, and capital required by the initiative. The negative relationship is greater in high income group, as showed in Table 4. In low income group (Table 3), time, cost, and number of procedures are almost the same between men and woman, as the strong positive correlation expresses. Some differences between genders exist, but they are slightly significant. In general, the positive correlation between being a man and starting a business is greater than in case of being a woman. Almost the same occurs in high income group (Table 4). 
Table 3

Correlation Statistic: Low and Low Medium Income

\begin{tabular}{|c|c|c|c|c|c|c|c|c|}
\hline & $\begin{array}{l}\text { Starting a } \\
\text { business- } \\
\text { DTF } \\
\text { —starting a } \\
\text { business }\end{array}$ & $\begin{array}{l}\text { Starting a } \\
\text { business- } \\
\text { procedures } \\
\text {-men } \\
\text { (number) }\end{array}$ & $\begin{array}{l}\text { Starting a } \\
\text { business- } \\
\text { time-men } \\
\text { (days) }\end{array}$ & $\begin{array}{l}\text { Starting a } \\
\text { business- } \\
\text { cost-men } \\
\text { (\% of income } \\
\text { per capita) }\end{array}$ & $\begin{array}{l}\text { Starting a } \\
\text { business- } \\
\text { procedures- } \\
\text { women } \\
\text { (number) }\end{array}$ & $\begin{array}{l}\text { Starting a } \\
\text { business- } \\
\text { time-- } \\
\text { women } \\
\text { (days) }\end{array}$ & $\begin{array}{l}\text { Starting a } \\
\text { business- } \\
\text { cost- } \\
\text { women (\% of } \\
\text { income per } \\
\text { capita) }\end{array}$ & $\begin{array}{l}\text { Starting a } \\
\text { business- } \\
\text { minimum } \\
\text { capital (\% of } \\
\text { income per } \\
\text { capita) }\end{array}$ \\
\hline $\begin{array}{l}\text { Starting a } \\
\text { business- } \\
\text { DTF- } \\
\text { starting a } \\
\text { business } \\
\end{array}$ & 1 & & & & & & & \\
\hline $\begin{array}{l}\text { Starting a } \\
\text { business- } \\
\text { procedures- } \\
\text { men } \\
\text { (number) }\end{array}$ & -0.63014 & 1 & & & & & & \\
\hline $\begin{array}{l}\text { Starting a } \\
\text { business- } \\
\text { time-men } \\
\text { (days) }\end{array}$ & -0.64849 & 0.512531 & 1 & & & & & \\
\hline $\begin{array}{l}\text { Starting a } \\
\text { business- } \\
\text { cost-men } \\
\text { (\% of income } \\
\text { per capita) }\end{array}$ & -0.55405 & 0.243631 & 0.346052 & 1 & & & & \\
\hline $\begin{array}{l}\text { Starting a } \\
\text { business- } \\
\text { procedures- } \\
\text { women } \\
\text { (number) } \\
\end{array}$ & -0.63896 & 0.994541 & 0.514737 & 0.255541 & 1 & & & \\
\hline $\begin{array}{l}\text { Starting a } \\
\text { business- } \\
\text { time-- } \\
\text { women } \\
\text { (days) } \\
\end{array}$ & -0.6491 & 0.512062 & 0.999964 & 0.346959 & 0.515159 & 1 & & \\
\hline $\begin{array}{l}\text { Starting a } \\
\text { business- } \\
\text { cost-women } \\
\text { (\% of income } \\
\text { per capita) }\end{array}$ & -0.55406 & 0.243613 & 0.346041 & 1 & 0.255532 & 0.346948 & 1 & \\
\hline $\begin{array}{l}\text { Starting a } \\
\text { business- } \\
\text { minimum } \\
\text { capital (\% of } \\
\text { income per } \\
\text { capita) }\end{array}$ & -0.41306 & 0.186093 & 0.118425 & 0.113548 & 0.206113 & 0.12005 & 0.113549 & 1 \\
\hline
\end{tabular}

Source: our elaboration. 
Table 4

Correlation Statistic:Upper Middle and High Income

\begin{tabular}{|c|c|c|c|c|c|c|c|c|}
\hline & $\begin{array}{l}\text { Starting a } \\
\text { business- } \\
\text { DTF- } \\
\text { starting a } \\
\text { business }\end{array}$ & $\begin{array}{l}\text { Starting a } \\
\text { business- } \\
\text { procedures } \\
\text { —men } \\
\text { (number) }\end{array}$ & $\begin{array}{l}\text { Starting a } \\
\text { business-t } \\
\text { ime-men } \\
\text { (days) }\end{array}$ & $\begin{array}{l}\text { Starting a } \\
\text { business- } \\
\text { cost-men } \\
\text { (\% of } \\
\text { income per } \\
\text { capita) }\end{array}$ & $\begin{array}{l}\text { Starting a } \\
\text { business- } \\
\text { procedures } \\
\text {-women } \\
\text { (number) }\end{array}$ & $\begin{array}{l}\text { Starting a } \\
\text { business- } \\
\text { time-- } \\
\text { women } \\
\text { (days) }\end{array}$ & $\begin{array}{l}\text { Starting a } \\
\text { business- } \\
\text { cost- } \\
\text { women (\% } \\
\text { of income } \\
\text { per capita) }\end{array}$ & $\begin{array}{l}\text { Starting a } \\
\text { business- } \\
\text { minimum } \\
\text { capital (\% } \\
\text { of income } \\
\text { per capita) }\end{array}$ \\
\hline $\begin{array}{l}\text { Starting a business_-DTF } \\
\text { —-starting a business }\end{array}$ & 1 & & & & & & & \\
\hline $\begin{array}{l}\text { Starting a business- } \\
\text { procedures—-men (number) }\end{array}$ & -0.88626 & 1 & & & & & & \\
\hline $\begin{array}{l}\text { Starting a business-time- } \\
\text { men (days) }\end{array}$ & -0.62851 & 0.483398 & 1 & & & & & \\
\hline $\begin{array}{l}\text { Starting a business-cost- }- \\
\text { men (\% of income per } \\
\text { capita) }\end{array}$ & -0.62183 & 0.449707 & 0.516566 & 1 & & & & \\
\hline $\begin{array}{l}\text { Starting a business- } \\
\text { procedures-women } \\
\text { (number) }\end{array}$ & -0.88591 & 0.995693 & 0.487428 & 0.447334 & 1 & & & \\
\hline $\begin{array}{l}\text { Starting a business-time- } \\
\text { women (days) }\end{array}$ & -0.6292 & 0.484146 & 0.999982 & 0.51657 & 0.488726 & 1 & & \\
\hline $\begin{array}{l}\text { Starting a business- } \\
\text { cost—women (\% of income } \\
\text { per capita) }\end{array}$ & -0.62183 & 0.449702 & 0.516567 & 1 & 0.447332 & 0.516572 & 1 & \\
\hline $\begin{array}{l}\text { Starting a business- } \\
\text { minimum capital (\% of } \\
\text { income per capita) }\end{array}$ & -0.39647 & 0.218756 & 0.038601 & 0.097067 & 0.242639 & 0.040448 & 0.097064 & 1 \\
\hline
\end{tabular}

Source: our elaboration.

\section{Discussion}

Our findings show that the greater is the number of procedures, time to enter the market, costs, and paid-in minimum capital, the harder is to start a (social) business. Though, the implementation of public policies for supporting entrepreneurship in underdogs individuals slightly eases this effect. In fact, there are different simplifications, forms of support and incentives (monetary and non monetary) for social entrepreneurship and disadvantaged categories. As the consequence, although underdogs still have a poor access to financial funds and possibility of starting a business, for them it is easier to start up a venture than for high income individuals. In other words, there are many incentives for social ventures and other forms of support for those individuals who have a low income and are willing to start a social business. Incentives are lower when the individual has a high income and in non-social ventures. Also, simplification in procedures eases the starting of a business more for low income group than for high income group.

Women still encounter numerous obstacles to become entrepreneur, usually more than man. To answer to our research questions, our findings confirm hypotheses: gender and social status impact the starting of a (social) business.

\section{Limitations}

This study has different limitations. First, the adopted methodology does not allow disentangling causal relationships. Second, we consider few independent variables, which we control for income and gender. Though, the entrepreneurship phenomenon, also in social business, is extremely complex. There are plenty of 
factors which can better explain and motivate our results, thus offering a broader understanding of the phenomenon. Additionally, personal traits and other individual characteristics then are not detected in aggregated data sets which could impact these results in a significant manner. Another important aspect that this study does not take under consideration is the effect of specific public policies, including policies for access to financial funds. Finally, the study does not offer insights on the process, the reason why to start a social business and the type of social goals, as well as the relationship between the creation of shareholder value and social value.

\section{Originality of the Work and Implications for Theory and Practice}

This paper contributes to deepening the understanding of social entrepreneurship by anchoring its determinants to objective characteristics of individuals, differently from prior studies.

Also, most scholars in this research stream offer qualitative and narrative analyses, whilst quantitative investigations are pretty rare (Mair \& Noboa, 2006; Mair \& Marti, 2006). Our contribution grounds its roots on solid, even explorative, empirical basis. Further, it offers some unexpected insights. We find that over-time effects of gender and income blur and their impact is less marked. Thus, though it is still hard to start a business, social entrepreneurship actually promotes social development by raising social status of founders.

Results can be used by policy makers, as a grid to select future actions for entrepreneurship promotion between marginalized groups of individuals. As instance, they suggest that policy makers should pay attention to incentives for women entrepreneurship.

\section{Conclusions and Suggestion for Future Research Debate}

This study contributes to tackling a main literature gap in the research field: the scarcity of empirical analyses on objective determinants of social entrepreneurship. We study gender and income characteristics at individual level and we observe how they interplay with starting a (social) business. We find that income relatively matters in this domain, as well as gender.

Our results' implications are not limited to social entrepreneurship. On the contrary, they contribute to advancing knowledge in overall entrepreneurship field. Though, our analysis does not allow detecting causal relationships and is made of a small number of variables. Objective and context determinants of social entrepreneurship deserve a greater attention in future. A better understanding of these matters can be achieved by using micro-data. Specifically, results of our study open up to the following research questions: (i) how do specific policies impact starting a social venture? (ii) how do such policies affect income and gender issues? (iii) what are main context determinants? (iiii) what is the worth of other socio-demographic factors? (iiiii) is being an underdog a reason to become a social entrepreneur?

Hopefully, future papers will solve such riddles, whose answer might have a crucial social impact.

\section{References}

Alvord, S. H., Brown, L. D., \& Letts, C. W. (2004). Social entrepreneurship and societal transformation: An exploratory study. The Journal of Applied Behavioral Science, 40(3), 260-282.

Anderson, A. R., \& Miller, C. J. (2003). “Class matters”: Human and social capital in the entrepreneurial process. The Journal of Socio-Economics, 32(1), 17-36.

Anderson, R. B., Dana, L. P., \& Dana, T. E. (2006). Indigenous land rights, entrepreneurship, and economic development in Canada: “Opting-in” to the global economy. Journal of world business, 41(1), 45-55.

Bates, T. (2011). Minority entrepreneurship. Foundations and Trends ${ }^{\circledR}$ in Entrepreneurship, 7(3-4), 151-311. 
Chell, E., Spence, L. J., Perrini, F., \& Harris, J. D. (2016). Social entrepreneurship and business ethics: Does social equal ethical? Journal of Business Ethics, 133(4), 619-625.

Cho, A. H. (2006). Politics, values and social entrepreneurship: A critical appraisal. In Social entrepreneurship (pp. 34-56). London: Palgrave Macmillan.

Choi, N., \& Majumdar, S. (2014). Social entrepreneurship as an essentially contested concept: Opening a new avenue for systematic future research. Journal of Business Venturing, 29(3), 363-376.

Datta, P. B., \& Gailey, R. (2012). Empowering women through social entrepreneurship: Case study of a women's cooperative in India. Entrepreneurship Theory And Practice, 36(3), 569-587.

De Clercq, D., \& Honig, B. (2011). Entrepreneurship as an integrating mechanism for disadvantaged persons. Entrepreneurship \& Regional Development, 23(5-6), 353-372.

Defourny, J., \& Nyssens, M. (2010). Conceptions of social enterprise and social entrepreneurship in Europe and the United States: Convergences and divergences. Journal of Social Entrepreneurship, 1(1), 32-53.

Fairlie, R. W. (2005). Entrepreneurship and earnings among young adults from disadvantaged families. Small Business Economics, 25(3), 223-236.

Fairlie, R. W., \& Lofstrom, M. (2015). Immigration and entrepreneurship. In Handbook of the economics of international migration (Vol. 1, pp. 877-911). North-Holland.

Giannetti, M., \& Simonov, A. (2004). On the determinants of entrepreneurial activity: Social norms, economic environment and individual characteristics. Swedish Economic Policy Review, 11(2), 269-313.

Grimm, R., Fox, C., Baines, S., \& Albertson, K. (2013). Social innovation, an answer to contemporary societal challenges? Locating the concept in theory and practice. Innovation: The European Journal of Social Science Research, 26(4), $436-455$.

Herring, C. (2004). Open for business in the black metropolis: Race, disadvantage, and entrepreneurial activity in Chicago's inner city. The Review of Black Political Economy, 31(4), 35-57.

Hibbert, S. A., Hogg, G., \& Quinn, T. (2005). Social entrepreneurship: Understanding consumer motives for buying The Big Issue. Journal of Consumer Behaviour, 4(3), 159-172.

Hiller, J. (2013). The benefit corporation and corporate social responsibility. Journal of Business Ethics, 118(2), $287-301$.

Hoogendoorn, B. (2016). The prevalence and determinants of social entrepreneurship at the macro level. Journal of Small Business Management, 54(S1), 278-296.

Jack, S. L., \& Anderson, A. R. (1999). Entrepreneurship education within the enterprise culture: producing reflective practitioners. International Journal of Entrepreneurial Behavior \& Research, 5(3), 110-125.

Kerlin, J. A. (2006). Social enterprise in the United States and Europe: Understanding and learning from the differences. Voluntas: International Journal of Voluntary and Nonprofit Organizations, 17(3), 246.

Korten, D. C. (1980). Community organization and rural development: A learning process approach. Public Administration Review, 40(5), 480-511.

Lyons, E., \& Zhang, L. (2017). The impact of entrepreneurship programs on minorities. American Economic Review, 107(5), 303-307.

Mair, J., \& Marti, I. (2006). Social entrepreneurship research: A source of explanation, prediction, and delight. Journal of World Business, 41(1), 36-44.

Mair, J., \& Noboa, E. (2006). Social entrepreneurship: How intentions to create a social venture are formed. In Social entrepreneurship (pp. 121-135). London: Palgrave Macmillan.

Marlow, S., Carter, S., \& Shaw, E. (2008). Constructing female entrepreneurship policy in the UK: Is the US a relevant benchmark? Environment and Planning: Government and Policy, 26(2), 335-351.

Masurel, E., Nijkamp, P., Tastan, M., \& Vindigni, G. (2002). Motivations and performance conditions for ethnic entrepreneurship. Growth and Change, 33(2), 238-260.

Miller, D., \& Le Breton-Miller, I. (2016). Underdog Entrepreneurs: A model of challenge-based entrepreneurship. Entrepreneurship: Theory and Practice, 41(1), 7-17.

Miller, T. L., Grimes, M. G., McMullen, J. S., \& Vogus, T. J. (2012). Venturing for others with heart and head: How compassion encourages social entrepreneurship. Academy of Management Review, 37(4), 616-640.

Selsky, J. W., \& Smith, A. E. (1994). Community entrepreneurship: A framework for social change leadership. The Leadership Quarterly, 5(3-4), 277-296.

Volery, T. (2007). Ethnic entrepreneurship: A theoretical framework. In Dana, L. P., Handbook of research on ethnic minority entrepreneurship: A co-evolutionary view on resource management (pp. 1, 30-41). Cheltenham: Edward Elgar Publishing. 